\title{
FEEDING CAPACITY OF THE SPIDER Anelosimus studiosus HENTZ (ARACHNIDA :THERIDIIDAE) FED ON DIFFERENT LARVAE OF LEPIDOPTERUS PESTS (GELECHIIDAE AND NOCTUIDAE \\ Abo-Zaid, Amal E.; A. M. Khalil and H. A. Zouz \\ Plant Protection Res. Inst. Agric. Res. Center Dokki-Giza, Egypt
}

\begin{abstract}
Some biological aspects of the spider Anelosimus studiosus (Hentz) fed on first instar larvae of Pectinophora gossypiella (Saund.) and the second instar larvae of Spodoptera littoralis (Boisd.) were studied under laboratory conditions of $25 \pm 1^{\circ} \mathrm{C}$ and $65 \pm 5 \% \mathrm{RH}$. The female life cycles spider averaged 78.5 and 85.48 days, while it was 83.83 and 75.1 days for male when they fed on the above prey, respectively. Adult female and male consumed (129.66 \& 101.30) and (103.30 \& 785.60) larvae of $P$. gossypiella and $S$. littoralis, respectively. Adult female lived for 39.3 and 41.3 days on $P$. gossypiella and $S$. littoralis and deposited an average of $41.7 \& 26.7$ eggs when it fed on larvae of the above mentioned insects, respectively.
\end{abstract}

\section{INTRODUCTION}

Spiders are considered one of the important biological control agents of arthropod pests infesting different crops and fissures in soils (Levy, 1963 and El- Erksousy, 2000 \& 2003). El- Erksousy et al., 2002 and Sallam et al. 2010 studied the biological aspects of some species of family Theridiidae as biological control agents of Aphis craccivora, Spodoptera littoralis (Boisd.) and Tetranychus urticae koch. Ahmed, 1998 reared on mixed diet of aphids \& mites, respectively. Also, several authors studied the behaviour and development of several com footed spiders (Brach, 1977, Riechert and Hederick, 1993; Riechert and Maupin, 1998; Sih et al. 2004; Jones et al. 2007 and Riechert \& Jones, 2008).

The present work aims to study some biological aspects of the spider Aneiosjmus studiosus reared on second larval instar of the cotton leaf worm Spodoptera littoralis and the first instar of larvae of the pink bollworm Pectinophora gossypiella (Saund.).

\section{MATERIALS AND METHODS}

Rearing inset preys:

Larvae of Pectinophora gossypiella (Saund.) were reared on a modified artificial diet described by Rashad and Ammer (1985), while larvae of Spodoptera littoralis (Boisd.) were reared on fresh castor bean leaves Ricinus communis under laboratory conditions of $25 \pm 1^{\circ} \mathrm{C}$ and $65 \pm 5 \% \mathrm{RH}$.

Rearing the predator spider Anelosimus studiosus Hentz:

Adults and egg sacs of $A$. studiosus were collected from olive trees at El-Arish, Sinai governorate. 
Abo-Zaid, Amal E. et al.

A. studiosus adult females \& males were confined as couples in translucent plastic containers, $3 \mathrm{~cm}$ in diameter and $15 \mathrm{~cm}$ in depth until females laid their egg- sacs. The egg sacs were observed daily until hatching took place. The newly hatched spiderlings were reared singly for one generation on first instar larvae of $P$. gossypiella (PBW) and second instar larvae of $S$. littoralis (CLW)

Egg sacs collected from the females of the first generation were kept singly in glass tubes and allowed to hatch. The newly hatched spiderlings were transferred singly to glass tubes $(7 X 3.5 \mathrm{~cm})$. The hatched spiderlings were divided to two groups, each of 45 tubes. The first group was reared on first instar larval of $P$. gossypiella, while the second one reared on the second instar of $S$. littoralis. Sufficient numbers of consumed prey larvae were offered daily and increased as the predator spiderlings grew up.

Also, the numbers of deposited egg-sacs and the number of eggs per sac were counted as well as duration of pre-ovipostion, ovipostion, post ovipostion, longevity of females and males were estimated. Total consumption for each prey were assessed and examined by analysis of variance (ANOVA) using Costat program.

\section{RESULTS AND DISCUSSION}

\section{Incubation periods of eggs:}

The spider Anelosimus studiosus Hentz was successfully reared on first instar larvae of the Pink bollworm P. gossypiella (Saund.) and second instar larvae of the cotton leaf worm S. littoralis (Boisd.) which consider the main lepidopterous pests in Egyptian cotton fields. Both spider females and males pass through four spiderlings (larval instars) before reaching adult stage. As shown in Table (1) egg incubation period lasted 15.30 and 13.30 days when reared on the two pests, respectively at $25 \pm 1^{\circ} \mathrm{C}$ and $65 \pm 5 \%$ R.H. Developmental time of spiderling stage:

Duration of the spiderlings generally increased with successive instars except for female and male third spiderlings on $P$. gossypiella. However total duration of the spiderlings (immatures) averaged (78.50 \& 79.45) days for spider female and (85.80 \& 75.40) days for males when they reared on $P$. gossypiella and $S$. littoralis respectively.

Also, data in Table (1) show that the different instar period of spiderlings female fed on PBW lasted 13.3, 18.3, 11.3 and 20.3 day while those fed on CLW lasted for $11.3,16.25,19.6$ and 19.0 days from first to fourth instar, respectively, On the other hand the average duration male were 14.3, 18.6, 14.3 and 23.3 days on PBW and 10.0, 15.6, 19.3 and 17.6 days on CLW, respectively. El- Erksousy (2002) recorded that the total duration of male and female of Anelosimus oulicus were 61.2 and 67.2, respectively, when reared on $S$. littoralis 
Table (1): Developmental stage of Anelosimus studiosus Hentz reared on P. gossypiella and S. littoralis

\begin{tabular}{|c|c|c|c|c|c|c|c|c|}
\hline \multirow{3}{*}{$\begin{array}{l}\text { Immature } \\
\text { instars }\end{array}$} & \multicolumn{8}{|c|}{ Duration in days \pm S.E. } \\
\hline & 오오 & 오오 & \multirow{2}{*}{$P$} & \multirow{2}{*}{ LSD } & $\hat{0} 0^{\lambda}$ & $\hat{0} 0^{\lambda}$ & \multirow{2}{*}{$P$} & \multirow{2}{*}{ LSD } \\
\hline & p. gossypiella & S. littoralis & & & p. gossypiella & S. littoralis & & \\
\hline Egg & $15.30 \pm 0.9 \mathrm{~b}$ & $13.30 \pm 1.1 \mathrm{a}$ & $0.02^{*}$ & 0.83 & $15.3 \pm 0.1 \mathrm{~b}$ & $13.30 \pm 0.1 \mathrm{a}$ & $0.00^{* \star}$ & 0.37 \\
\hline $1^{\text {st }}$ spiderling & $13.3 \pm 0.8 \mathrm{a}$ & $11.3 \pm 0.3 \mathrm{~b}$ & $0.001^{* *}$ & 0.68 & $14.3 \pm 0.4 a$ & $10.0 \pm 0.4 \mathrm{~b}$ & $0.00^{\star \star}$ & 0.68 \\
\hline $2^{\text {nd }}$ spiderling & $18.3 \pm$ & $16.25 \pm 0.8 b$ & $0.00^{\star *}$ & 0.35 & $18.6 \pm 0.3 a$ & $15.6 \pm 0.3 b$ & $0.00^{* *}$ & 0.68 \\
\hline $3^{\text {rd }}$ spiderling & $11.3 \pm 0$ & $19.6 \pm 0.5 a$ & $0.000^{\star *}$ & 0.48 & $14.3 \pm 0.5 b$ & $19.3 \pm 0.3 a$ & $0.00^{* \star}$ & 0.277 \\
\hline $4^{\text {th }}$ spiderling & $20.3 \pm 0.4 a$ & $19.0 \pm 0.5 b$ & $0.01^{*}$ & 0.84 & $23.3 \pm 0.8 a$ & $17.6 \pm 0.6 b$ & $0.00^{* *}$ & 0.48 \\
\hline $\begin{array}{l}\text { Total } \\
\text { immature } \\
\text { stages }\end{array}$ & $78.5 \pm 1.5 b$ & $79.45 \pm 3.2 \mathrm{a}$ & $0.000^{* *} \mid$ & 0.24 & $85.8 \pm 3.6 \mathrm{a}$ & $75.40 \pm 6.1 b$ & $0.00^{* *}$ & 0.46 \\
\hline
\end{tabular}

\section{Feeding Capacity:}

Table (2) showed that the highly significant difference occurred in feeding capacity of $A$. studiosus between spiderlings instars when fed on first instar larvae of $P$. gossypiella and second instar larvae of $S$. littorals. Obtained data cleared that the mean consumption rate increased with the progressive spiderlings instar. Also, data revealed that the average of total consumption of the tested predator $A$. studiosus from $1^{\text {st }}$ to $4^{\text {th }}$ instars fed on each of the two prey $P$. gossypiella \& S. littorals were 193.1, 243.5,167.9 and 226.9 prey/female \& male, respectively. On the other hand immature instar per female or male spider consumed an average 19.6, 23.6, 58.5 and 89.6 prey/female and 20.3, 24.0, 36.3 and 87.3 larvae/male for PBW and 38.6, 49.6, 61.0 and 94.3 prey/female and $37.0,48.3,53.3$ and 88.3 larvae prey/male for $S$.littoralis larvae respectively.

Table (2): Food consumption of Anelosimus studiosus reared on $P$. gossypiella and S. littoralis.

\begin{tabular}{|c|c|c|c|c|c|c|c|c|}
\hline \multirow{3}{*}{ Immature instars } & \multicolumn{2}{|c|}{ Prey species } & \multirow{3}{*}{$\mathbf{P}$} & \multirow{3}{*}{ LSD } & \multicolumn{2}{|c|}{ Prey species } & \multirow{3}{*}{$\mathbf{P}$} & \multirow{3}{*}{ LSD } \\
\hline & 우앙 & 우 & & & $\sigma^{\lambda}$ & $\hat{\sigma}$ & & \\
\hline & p. gossypiella & S. littoralis & & & \multicolumn{2}{|c|}{ p. gossypiella S. littoralis } & & \\
\hline iderling & $19.6 \pm 0.8 b$ & $38.6 \pm 1.3 a$ & $0.00^{* *}$ & 0.84 & $20.3 \pm 0.3 b$ & $37.0 \pm 0.1 \mathrm{a}$ & 0.0 & 0.48 \\
\hline $2^{\text {nd }}$ spiderling & $23.3 \pm 0.6 b$ & $49.6 \pm 2.6 a$ & 0.0 & 0.68 & $24.0 \pm$ & $48.3 \pm 1.6 \mathrm{a}$ & 0. & 0.83 \\
\hline $3^{\text {rd }}$ spiderling & $58.3 \pm 0.6 b$ & $61.0 \pm 1.2 \mathrm{a}$ & & 1.29 & $36.3=$ & $53.3 \pm 1.6 \mathrm{a}$ & 0. & 0.73 \\
\hline $4^{\text {th }}$ spide & $89.6 \pm 0.6 a$ & $94.3 \pm 2.9 \mathrm{~b}$ & 0. & 0.96 & $87.3 \pm$ & $88.3 \pm 1.8 \mathrm{a}$ & 0. & 0.48 \\
\hline Total immature stages & $193.1 \pm 4.6 b$ & $243.5888 \pm 5.5 a$ & 0.00 & 1.6 & $167.9 \pm 4.5 b$ & $226.9 \pm a$ & $0.00^{\prime}$ & 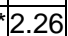 \\
\hline
\end{tabular}

\section{Ovipostion period:}

Table (3) showed that the pre-ovipostion, ovipostion and post ovipostion periods for $A$. studiosus when reared on first larvae of $P$. gossypiella, these averaged $9.3,6.3$ and 23.3 days, respectively, while, prolonged to $10.3,9.3$ and 19.3 , days on second instar larvae of $S$. littoralis at the same pattern.

Also, the number of deposited eggs/sac was affected by prey. Its average was (41.7) for female when fed on $P$. gossypiella, compared with 26.7 eggs on $S$. littoralis, . Also, high significant differences occurred between eggs/sac hatchability its percentages was 75.6 and $69.3 \%$, when female fed on the above mentioned prey, respectively. 
Abo-Zaid, Amal E. et al.

3

546 
El- Erksousy (2002) recorded that the adult female of $A$. oulicus laid its eggs in sacs, each contained 15to 20 eggs.

Generally, A. studiosus may considered to be one of the biocontrol agents of newly hatched larvae of the pink bollworm time before penetrate cotton boll and on $1^{\text {st }} \& 2^{\text {nd }}$ larvae of cotton leaf worm.

\section{REFERENCES}

Ahmed, N.F.R. (1998): Studies on some arthropods in habiting cucurbits and beans. M.sc thesis, Fac. Of Agric. Cairo Univ.

Brach, V. (1977): Anelosimus studiosus (Araneae: Therridiidae ) and the evolution of qasisociality in theridiid spiders. Evolution, 31, 154-161.

El- Erksousy, M.H. (2000): Studies on some true spiders in Egypt. Ph. D.Thesis, Fac. Agric. Al- Azhar Univ., 123pp.

El-Erksousy, M.H. (2003): Biology of the spider, Theridion egyptium Fawzy and El-Erksousyfed on Spodoptera littoralis larvae. Bull.Ent.Soc.Egypt, 21-24 Decemb.

El-Erksousy, M.H.; Amira, Shoeib, A. and Dahi, H. F. (2002) Studies on biological control using the spider Anelosimus oulicus (Theridiidae)... $2^{\text {nd }}$ International conference Plant Protection Research Institute , Cairo, Egypt ,21-24 December.

Jones, J. C., Riechert, S. E., Dalrymple, S.E. and Parker, P.G., 2007. Fostering model explains variation in levels of sociality in a spider system. Animal Behaviour, 73, 195-204.

Levy, H.W. (1963): American spiders the Theidion (Araneae:Theridiidae). Bull. Mus. Comp. Zool-harv., 129:481-589.

Rashad, A.M. and Ammar, E. D. (1985). Mass rearing of the spiny bollworm, Earias insulana on semi- artificial diet. Bull, Soc., ent., Egypt, 65: 239244.

Riechert, S.E. and Hedrick, A. V. (1993): A test for correlation among fitness linked behavioural traits in the spider Agelenopss aperta (Araneae, Agelenidae ). Animal behaviour, 46, 669-675.

Riechert, S.E. and Jones, J. C. (2008): Phenotypic variation in the social behviour of the spider Anelosimus studiosus along a latitudinal gradient. Animal behaaviour, 75, 1893-1902.

Riechert, S.E. and Maupin, J. L. (1998): Spider effects on pray: tests for superfluous killing in five web-buiders. In: Proceeding of the $17^{\text {th }}$ European Colloguium of Archnology, Edinburgh 1997 (Ed. By P.A. Selden ), pp. 203-210. Burnham Beeches, Buckinghamshire: British Archnological Society.

Sallam, M.E.Gehan; Abdel-Azeim, Nahla and El-Kawas, H.M. G. (2010): Biodiversity of spiders associated with cotton and maize in Sharki governorate with special reference to the spider Kochiura aulica (Kooh).

Sih, A. Bell, A. M. and Johnson, J. C. (2004): Behavioral syndromesa : an ecological and evolutionary overview. Trends in Ecology and evolution, 19, 372-378. 
Abo-Zaid, Amal E. et al.

تغذيـة المفترس العنكبوتي Anelosimus studiosus علـي دودة اللوز القرنفلية و دودة ورق القطن القني

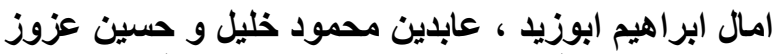
معهل بحوث وقاية النباتات مركز البحوث الزراعية الدقي الجيزة

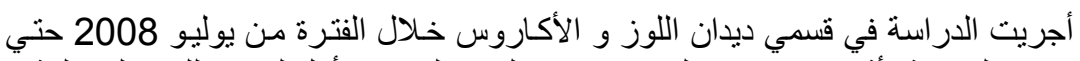

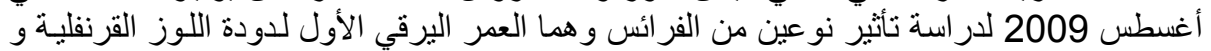

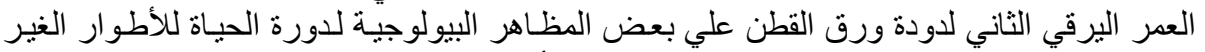

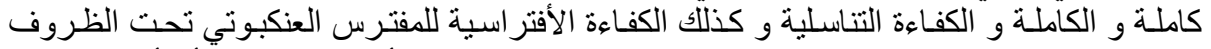

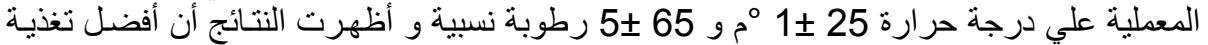

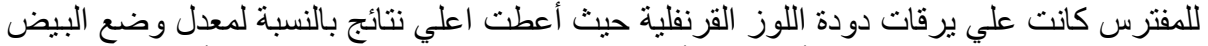

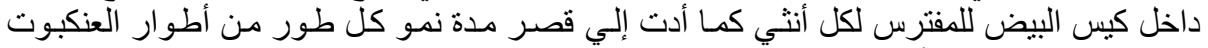

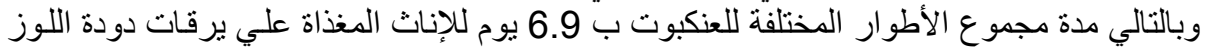

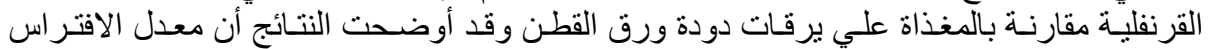

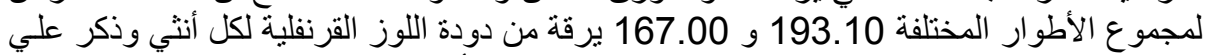
التوالي و 198.6 و 226.9 يرقة من دودة ورق القطن لكل أنثي وذكر علي التو الي. للي.

كلية الزراعة - جامعة المنصورة

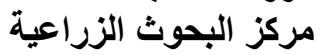

قام بتحكيم البحث

أ. أد / عمر عبد البح الحميد نصار

أ.د / أدن على على احمد طه نه 
J. Plant Prot. and Pathology, Mansoura Univ., Vol. 2 (5), May, 2011 
J. Plant Prot. and Pathology, Mansoura Univ., Vol. 2 (5): 543 - 548, 2011

Table (3): Ovipostion period, fecundity, longevity and food consumption of Anelosimus studiosus when reared on $P$. gossypiella and S. littoralis.at $25 \mathrm{C}+1$ and $65+5$ R.H.

\begin{tabular}{|c|c|c|c|c|c|c|c|c|c|}
\hline \multirow{2}{*}{ Food } & \multirow{2}{*}{$\begin{array}{c}\text { Pre } \\
\text { ovipostion } \\
\text { (days) }\end{array}$} & \multirow{2}{*}{$\begin{array}{l}\text { Ovipostion } \\
\text { (days) }\end{array}$} & \multirow{2}{*}{$\begin{array}{c}\text { Post } \\
\text { ovipostion } \\
\text { (days) }\end{array}$} & \multicolumn{2}{|c|}{ Fecundity } & \multicolumn{2}{|c|}{ Longevity } & \multicolumn{2}{|c|}{ Food consumption } \\
\hline & & & & $\begin{array}{c}\text { Total } \\
\text { eggs } \\
\text { inside } \\
\text { sac } \\
\end{array}$ & $\begin{array}{c}\% \\
\text { hatchability }\end{array}$ & 우우 & $\sigma^{\pi}$ & 우우 & के \\
\hline \begin{tabular}{|l|} 
gossypiella \\
gos
\end{tabular} & $\begin{array}{c}9.3 \pm 0.34 \\
(9-13)\end{array}$ & $\begin{array}{c}6.3 \pm 0.3 a \\
(6-7)\end{array}$ & $\begin{array}{c}23.3 \pm 0.174 \\
(20-25)\end{array}$ & $\begin{array}{c}41.7 \pm 10.3 \\
(25-60)\end{array}$ & $\begin{array}{c}75.60 \pm 3.0 \\
(70-80)\end{array}$ & $\begin{array}{c}39.0 \pm 1.5 \\
(36-41)\end{array}$ & $\begin{array}{c}31.60 \pm 1.6 \mathrm{a} \\
(30-35)\end{array}$ & $\begin{array}{c}129.66 \pm 8.01 \\
(119-145)\end{array}$ & $\begin{array}{c}101.3 \pm 3.2 a \\
(95-125)\end{array}$ \\
\hline S. Iittoralis & $\begin{array}{c}10.3 \pm 0.3 \\
(10-12)\end{array}$ & $\begin{array}{c}9.3 \pm 0.3 b \\
(9-10)\end{array}$ & $\begin{array}{c}19.3 \pm 0.7 \\
(18-20)\end{array}$ & $\begin{array}{c}26.7 \pm 1.69 \\
(25-30)\end{array}$ & $\begin{array}{c}69.3 \pm 2.3 \\
(65-70)\end{array}$ & $\begin{array}{c}41.3 \pm 1.4 \\
(39-44)\end{array}$ & $\begin{array}{c}21.66 \pm 1.7 \mathrm{~b} \\
(20-25) \\
\end{array}$ & $\begin{array}{c}103.3 \pm 8.9 \\
(90-120) \\
\end{array}$ & $\begin{array}{c}85.6 \pm 0.34 b \\
(85-97 \\
\end{array}$ \\
\hline LSD & & 1.308 & & 8.54 & 2.03 & & 6.54 & & 8.87 \\
\hline $\mathbf{P}$ & Ns & $0.003^{\star \star}$ & Ns & $0.014^{* *}$ & $0.006^{* *}$ & Ns & $0.013^{*}$ & $\mathrm{Ns}$ & $0.008^{\star \star}$ \\
\hline
\end{tabular}

